\title{
Investigating the Properties of the Vertisols at Kenana III and IV Towards Enhancing Management Practices (Sennar State - Sudan)
}

\author{
El-Abbas. Doka M. Ali ${ }^{1}$, John Aitken ${ }^{2}$, Neil R. Munro ${ }^{3}$ \\ ${ }^{1}$ Land Evaluation and Remote Sensing, College of Agricultural Studies, Sudan University of \\ Science and Technology, Shambat \\ ${ }^{2}$ International Consultant, Soil Survey and Land Evaluation, \\ ${ }^{3}$ International Consultant, Soil Survey and Land Evaluation, \\ adoka21@gmail.com; j.aitken@talk21.com; Neil.munro@dial.pipex.com
}

\begin{abstract}
A series of studies were initiated in Sudan in the early 1950s for utilization of the Nile Waters [19]. On the basis of these studies the Rosaries Dam was built on the Blue Nile. By the end of 2008 a programme to start the heightening of the dam was started with outlets for canals on both banks. At the same time further agricultural development on two irrigation projects, the Kenana and Rahad II commenced with soil surveys and irrigation design. The Kenana Area lies between the Blue Nile and the White Nile and runs south east to North West from Disa to Managil. Kenana Area is almost flat with predominantly clayey soils [21], [17]. Kenana III lies midway between the Blue Nile and the White Nile south of Sennar-Kosti railway line. Kenana IV area finally lies to the north west of Kenana III area.

The soil study area is partly semi-arid and partly arid, and experiences slight rainfall in the order of 350 $\mathrm{mm}$ in its northern edge, increasing to some $650 \mathrm{~mm}$ at its southern boundary near Jebel Dali. The soil surveys carried in the area were made at semi-detailed level and the key specifications are a field density of 1 observation each 100 ha and map scales of 1:50,000 and 1:100,000. Previously published soil survey information was reviewed and incorporated in these surveys. In these surveys a number of potential agricultural options in terms of adapted cropping patterns, systems of management and two methods of surface and pressure irrigation were considered for development [6]. The most dominant soils are the Vertisols which have high potential for crop production, but some constraints emerge affecting crop performance and decreasing yields. Those limitations are aspects of land degradation, manifested in deterioration of physical and chemical properties. Continuous cropping of Vertisols, through time, leads to compaction and eventually develops hardpan at the subsurface, reducing porosity, intensity of cracking and obliterating water movement. Such adverse effects are indicators of degraded soil physical properties. To minimize the concurrence of those hazards management procedures should adhere to land and crop management systems. Parallel to this approach, the fertility status is likely to decline due to intensive farming of some nutrient-depleting crops, but this nutrient deficiency is correctable through implementing a fertilizer programme. In the study area, some parameters are management-factors determining e.g. flat slope favouring uniform distribution of irrigation water through well designed irrigation and drainage network, and sub-soiling preparing proper seedbed. Those technical inputs if properly used and practiced they are expected to sustain crop production.
\end{abstract}


El-Abbas. Doka M. Ali, J ohn Aitken, Neil R. Munro; Investigating the Properties of the Vertisols at Kenana III and IV Towards Enhancing Management Practices (Sennar State - Sudan). Advances in Image and Video Processing, Volume 5 No 5, October (2017); pp: 11-20

Keywords: Vertisols, Kenana Area, Irrigated Agriculture; Soil survey; Landsat, Clay plain

\section{Introduction}

This study describes physical and chemical properties of soils at 322,322 ha situated in Kenana plain south of Gezira and Managil scheme. The area includes Kenana KIII and Kenana IV areas. Figure 1 shows the location of the study area. The Kenana III area lies to the west of Kenana II and is situated about half- way between the Blue and White Niles. The southern boundary is in the neighbourhood of Jebel Dali and the northern boundary about $10 \mathrm{~km}$ south of Jebel Moya. In the east, Kenana III is contiguous with Kenana II. In the west it adjoins the land being developed by the Kenana Sugar Company. The Kenana IV area lies to the north-west of Kenana III. It adjoins the land belonging to both the Kenana Sugar Company and Asalaya Sugar Project. In the north it adjoins the Es Shawal Extension of the Gezira Irrigated Scheme.

The climate of the study area lies in the semi-arid climatic zone [22]. Maximum temperatures of the hottest month (April or May) are 39-40 oC; whilst the mean minimum temperatures of the coldest month (December and January) are 13-17 Co. The average annual rainfall is $400-750 \mathrm{~mm}$ which falls mainly in the months of May-September, and is less than 44 per cent of the annual potential evapotranspiration. In at least one month the average rainfall exceeds the potential evapotranspiration (humid month); relative humidity being 20-40 per cent during most of the year rises to 70 per cent in the rainy season. The temperature and moisture regimes of the soil are used as criteria for taxonomic classification in the USDA Soil Taxonomy [21]. The study area has an isohyperthermic temperature regime (with the soil temperature at $50 \mathrm{~cm}$ depth) having an annual average above 22 Co and with less than 5 annual variation, and an Ustic moisture regime [22].

Different discussions indicated that the origin of superficial alluvial deposits of the study area belongs to two separate distinct regions which are referred to broadly as the Blue Nile Basin and the White Nile trough [24], [10]. Most of these regions consist of plains which are mantled by dark alkaline cracking Vertisol clays [5]. Apart from few scattered Jebels and low Azaza (remnants of in situ weathered ridges) the study area comprises a vast, flat, clay plain where slopes are mostly $\leqslant 1 \%$. The clay plain slopes very gently from 0 to $1 \%$ at a general elevation of $360 \mathrm{~m}$ to $400 \mathrm{~m}$. Within the plain gently undulating and undulating land is usually associated with shallow depressions and khors. The extent of these features is limited and land with slopes exceeding $1 \%$ amounts to no more than $1 \%$ of the overall area. In only a very few localities do slopes exceed $1 \%$.

The plant community in the study area consists of Acacia mellifera, Boscia senegalensis, and Cadada rotundifolia with scattered Acacia senegal, Acacia seyal and Balanites aegyptiaca and open areas of grasses and herbs. Acacia mellifera is continuously being exploited to provide a new land for cultivation. Because of its gum Arabic production Acacia senegal is not destroyed. In contrast to Acacia senegal, Acacia seyal is regularly cut for charcoal making. Balanites aegyptiaca is widespread in the area forming parkland. The most abundant grasses include Cymbopogon nervatus, Sorghum purpureo - sericum, Hyparrhenia rufa and Cenchrus ciliaris. Most of the study area has extensive rainfed farming, mostly sorghum. Much of this is undertaken by large semi-mechanised enterprises either on their own account or by contractors working for village communities. Sorghum is by far the most widespread crop. Over the whole area it consistently occupies just fewer than $70 \%$ of the farmed area (excluding the non-agricultural land). The percentage of sesame grown - about $6 \%$ - is constant throughout the area. Outside of the sorghum and sesame cropped lands, other crops (e.g. millet) combined to occupy only about $3 \%$ of the cropped area. 


\section{Materials and Methods}

A total of 4092 augers and 125 profile pits were studied (Table 1 and Figure 1) to characterize the Vertisols of the two areas. The location of all pit and auger sites based on GPS co-ordinates are shown on figure $1[6]$.

Table 1: Summary of Fieldwork for Soil Study of Kenana III and IV

\begin{tabular}{|c|c|c|c|c|c|}
\hline \multirow{2}{*}{$\begin{array}{c}\text { Study } \\
\text { area }\end{array}$} & Area & $\begin{array}{c}\text { Profile } \\
\text { pits }\end{array}$ & $\begin{array}{c}\text { Soil } \\
\text { augers }\end{array}$ & $\begin{array}{c}\text { Auger } \\
\text { samples }\end{array}$ & $\begin{array}{c}\text { Pit } \\
\text { samples }\end{array}$ \\
\cline { 2 - 6 } K III & ha & No. & No. & No. & No. \\
K IV & 113,882 & 80 & 2,616 & 7,848 & 332 \\
\hline Total & 322,322 & 125 & 4,092 & 12,276 & 191 \\
\hline
\end{tabular}

(Source: [6])

Field recording of soil auger sites and soil profiles was on standardized proformas and soils were described following the FAO "Guidelines for Soil Description" [9]. The observations included: Auger number; Surveyor; Data; GPS co-ordinates; Landform; Topography; Slope; Site; Surface features; Termitaria; Trees; Shrubs; Land Use; Water-table; Soil drainage class; Samples; Soil type; Depth of cracking; Soil code; Soil horizons (for each: boundary, colour, colour code, mottles, texture class, cracks, clay skins, slickensides, coarse fragments, reaction to dilute hydrochloric acid, calcium carbonate, iron-manganese, gypsum, and other features).

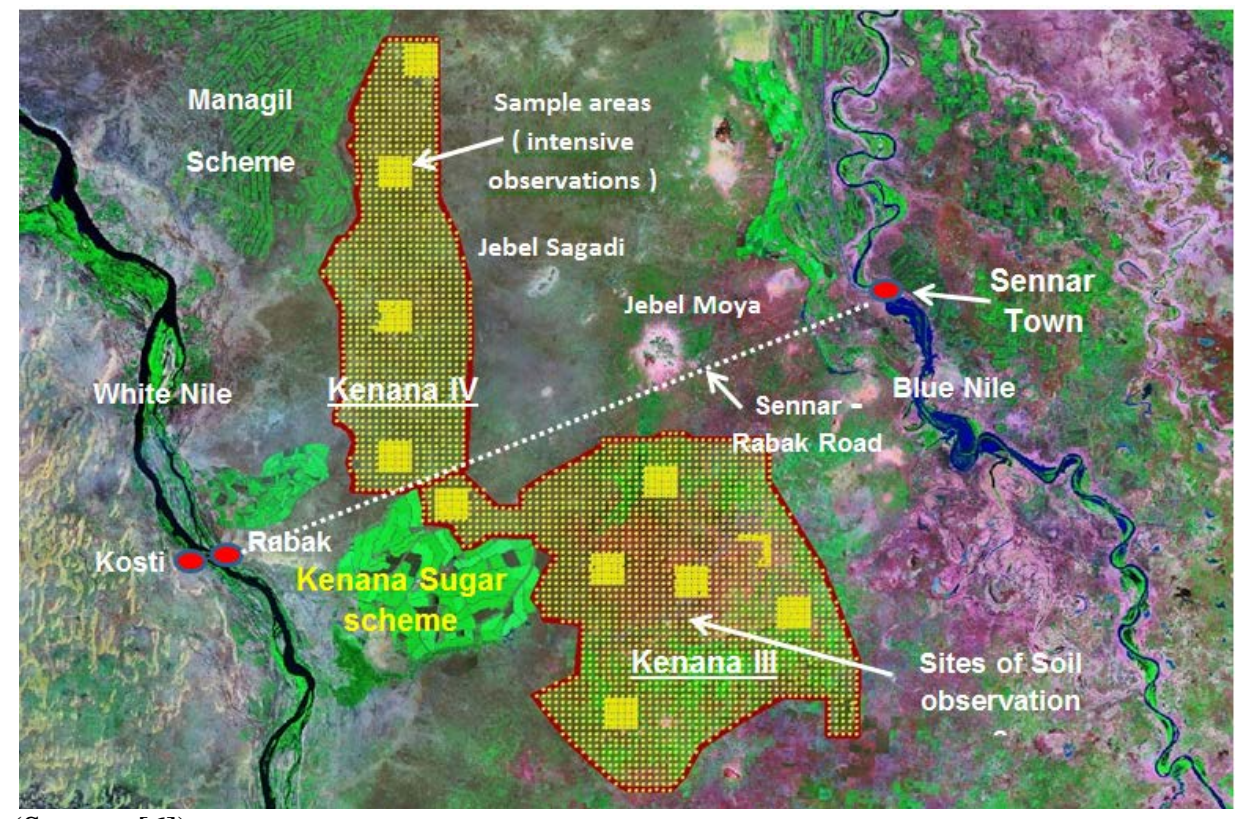

(Source: [6])

Figure 1: Kenana III and IV study areas on Landsat 2007 showing sampling sites and surrounding geographical features as part of the Central Clay Plain

\section{Results and Discussions}

\subsection{Physical properties}

All soils are $>2.0 \mathrm{~m}$ deep. The Vertisols clay varies in depth from 1.5 to $\geq 4.0 \mathrm{~m}$. The strata beneath the clay are heterogeneous brown, dark brown or dark yellowish brown silty clays, clay loams or sandy clay loams. With the exception of infiltration test, no tests were carried out for bulk density (BD), 
El-Abbas. Doka M. Ali, John Aitken, Neil R. Munro; Investigating the Properties of the Vertisols at Kenana III and IV Towards Enhancing Management Practices (Sennar State - Sudan). Advances in Image and Video Processing, Volume 5 No 5, October (2017); pp: 11-20

permeability or AWC on the Vertisols of the survey area because conventional methods for measuring permeability don't apply to shrink-swell montmorillonitic clays as the clays do accept water at first, swell and then seals and become almost impermeable. It had also been realized that it was impractical to take undisturbed sample to laboratory on daily bases [6]. The values for such untested parameters for similar soils were extracted [15].

The infiltration tests were conducted in the survey area using double ring infiltrometers. The values represent the basic infiltration rates which show almost consistent trends of $1.4 \mathrm{~cm} / \mathrm{h}$ due to the behavior of the homogenous soils of the survey area. The optimum basic infiltration rates for surface irrigation are considered to be in the range of 0.7 to $3.5 \mathrm{~cm} / \mathrm{h}$, although acceptable normal values range from about 0.3 to $6.5 \mathrm{~cm} / \mathrm{h}$ [15]. However, it is reported that the methods of infiltration measurement can suffer from a number of errors including, lack of adequate pre-wetting of dry expanding clays that need weeks of pre-wetting before major shrinkage cracks are closed; and soil disturbance effects during project development which may alter the soil - water intake characteristics [15].

\subsection{Chemical and mineralogical properties}

The field descriptions of the soil morphological feature and the chemical analyses of the soil units indicated that Typic and Chromic Vertisols are dominating [21], [8], [6]. It is assumed that the gently undulating, shallow depressions, gravels in top $60 \mathrm{~cm}$ and; calcium carbonate concretions in the top $60 \mathrm{~cm}$ phases of any soil unit will have a similar chemistry to that soil unit. The soil particle size analysis recorded clay content in the range of $55-75 \%$ that belongs to the clayey class in the FAO textural triangle and to the likely smectitic mineralogy [9]: the CEC values are fairly consistent with this range of clay content as shown in Table 2 an example taken from a previous survey [2].

Table 2: Clay mineralogy of a Vertisol soil at Central Clay Plain - West of Sennar

\begin{tabular}{|c|c|c|c|c|c|c|c|}
\hline $\begin{array}{c}\text { Profile } \\
\text { No. }\end{array}$ & Depth cm & Mt & Mi & Vm & Chl & $\mathbf{K}$ & $\mathbf{Q}$ \\
\hline \multirow{5}{*}{$\begin{array}{c}33 \\
C\end{array}$} & $0-10$ & $x x x x$ & & & & $x x$ & $\mathrm{t}$ \\
\hline & $10-42$ & $x x x x$ & & & & $x x$ & $\mathrm{t}$ \\
\hline & $42-89$ & $x x x x$ & & & & $x x$ & $\mathrm{t}$ \\
\hline & $89-146$ & $x x x x$ & & & & $x x$ & $\mathrm{t}$ \\
\hline & $146-180$ & $x x x x$ & & & & $x x$ & $\mathrm{t}$ \\
\hline
\end{tabular}

(Source: [2])

$\begin{array}{llllll}\text { Mt } & \text { Montmorillonite } & \text { Chl } & \text { Chlorite } & \text { Mi } & \text { Mica } \\ \mathbf{K} & \text { Kaolinite } & \text { Vm } & \text { Vermiculite } & \mathbf{Q} & \text { Quartz } \\ \mathbf{x} & \text { small } & \text { xx } & \text { moderate } & & \\ \text { xxx } & \text { large } & \text { xxxx } & \text { Predominant } & & \end{array}$

The total nitrogen and organic carbon contents are very low ranging from $0.02-0.04 \%$ to $0.6-0.8$ $\%$ respectively indicating very low organic matter content that coincides with the amounts usually present in an arid climate (Table 3 and Table 4). 
Table 3: Broad Ratings of Nitrogen Measurements

\begin{tabular}{|c|c|}
\hline $\begin{array}{c}\text { N content } \\
\text { Kjeldahl method } \\
\text { (\% of soil by weight) }\end{array}$ & Rating \\
\hline$<0.1$ & Very low \\
\hline $0.1-0.2$ & Low \\
\hline $0.2-0.5$ & Medium \\
\hline $0.5-1.0$ & High \\
\hline$>1.0$ & Very high \\
\hline
\end{tabular}

(Source: [15])

Table 4: Broad Ratings of Organic Carbon Measurements

\begin{tabular}{|c|c|}
\hline $\begin{array}{c}\text { Organic carbon content } \\
\text { Walkley-Black method (\% of } \\
\text { soil by weight) }\end{array}$ & Rating \\
\hline$<2$ & Very low \\
\hline $2-4$ & Low \\
\hline $4-10$ & Medium \\
\hline $10-20$ & High \\
\hline$>20$ & Very high \\
\hline
\end{tabular}

(Source: [15])

The available phosphorus, extracted with sodium carbonate buffered at $\mathrm{pH} 8.5$, varies between 1 and $5 \mathrm{ppm}$ and this amount is deficient for most crops and questionable for cereals and grasses - Table 5. The availability of phosphorus is critical to plant uptake because soil alkalinity $(\mathrm{pH} 8.5-9.0)$ causes fixation and/or formation of insoluble compounds. However, crops vary in response and therefore, requirement for fertilizers application need to be assessed after determining soil reactions [7].

Table 5: Interpretation of available phosphorus analyzed by Olsen's method

\begin{tabular}{|l|l|c|c|c|}
\hline Characteristic & \multicolumn{2}{|c|}{ Examples } & \multicolumn{3}{c|}{ Indicative available phosphorus values } \\
\cline { 3 - 5 } crop demand & & Deficient & Questionable & Adequate \\
\hline Low P & Grass, cereals, soybean, maize & $<4$ & $5-7$ & $>8$ \\
\hline Moderate P & Lucerne, cotton, sweet corn, tomatoes & $<7$ & $8-13$ & $>14$ \\
\hline High P & Sugar beet, potatoes, celery, onions & $<11$ & $12-20$ & $>21$ \\
\hline
\end{tabular}

(Source: [15])

The soil reaction is alkaline varying between mildly to strongly alkaline in really all the soils of the area. The $\mathrm{pH}$ values of the saturation extract range from $7.4-8.9$ increasing with the increase of the soil: water ratio (dilution effect). The $\mathrm{pH}$ values exceeding 9.1 are occasionally found in suspension 1:5 soil: water ratio. This high $\mathrm{pH}$ reduces the availability of micronutrients (such as $\mathrm{Fe}, \mathrm{Mn}, \mathrm{Zn}$, and $\mathrm{Cu}$ ) rendering them fixed into non-soluble forms, and hence the nutrient uptake by plants is retarded [1]. Although the reaction of the soil matrix is slightly to moderately calcareous, the $\mathrm{CaCO}_{3}$ content ranges from 3.7\%. Higher contents are infrequent and occur in the substratum in some profiles. However, these soils may contain $\mathrm{CaCO}_{3}$ more than that recorded in the analytical results. This is because the analyses were carried out in the "fine earth" ( $<2 \mathrm{~mm}$ dry soil sieved without any gravel) of the samples that passed the $2 \mathrm{~mm}$ sieve. In this regard, it is observed that $\mathrm{CaCO}_{3}$ concretions larger than $2 \mathrm{~mm}$ have been retained in the sieve as part of the gravel fraction of the sample which is not considered for the analysis. Smaller sized fragments of concretions will pass through the sieve and be included in the testing. The field method of applying $\mathrm{HCL}$ acid on the soil matrix to check the presence of $\mathrm{CaCO}_{3}$ proved to be a reliable indicator of soil calcareousness. 
El-Abbas. Doka M. Ali, John Aitken, Neil R. Munro; Investigating the Properties of the Vertisols at Kenana III and IV Towards Enhancing Management Practices (Sennar State - Sudan). Advances in Image and Video Processing, Volume 5 No 5, October (2017); pp: 11-20

The EC of the saturation extract rarely exceeded $4 \mathrm{dS} / \mathrm{m}$ at $25^{\circ} \mathrm{C}$ which indicates a very low hazard for salinity in these soils. The types of salts, as given from analysis of the exchangeable and soluble cations and anions, are dominantly sulphates followed by chlorides. Bicarbonate is present in little amounts while carbonates are either as a trace or not detected. The exchange complex in soils of this area is fully saturated with basic cations of $\mathrm{Ca}^{++}, \mathrm{Mg}^{++}, \mathrm{Na}^{+}$, and $\mathrm{K}^{+}$. Exchangeable $\mathrm{H}^{+}$and $\mathrm{Al}^{+++}$(exchange acidity) is therefore, non-existing. The Cation Exchange Capacity CEC ranges from $55-75 \mathrm{meq} / 100 \mathrm{gr}$ soil. Potassium and sodium are determined separately and results indicated that potassium is very low compared to sodium. The $\mathrm{Ca}^{++}+\mathrm{Mg}^{++}$are calculated by difference between the $\mathrm{CEC}$ and exchangeable $\mathrm{Na}^{+}+\mathrm{K}^{+}$, and therefore are not reported separately. This approach is adopted because of the occurrence of calcium sulphates in water adding more $\mathrm{Ca}^{++}$and $\mathrm{Mg}^{++}$to the soil solution which likely giving rise to erroneous estimates [6]. The Sodium Adsorption Ration (SAR) values are used to assess if there is any adverse effect of sodium in waters and soils. It is estimated using the following formula:



The practical experience indicates that the SAR values obtained by applying 1:5 soil- water rates methods are low and under estimated and this could be attributed to the following:

1- Solubility of $\mathrm{Ca}^{++}$and $\mathrm{Mg}^{++}$increases in higher soil-water ratios than $\mathrm{Na}$ + ;

2- The soil matrix is calcareous, containing $\mathrm{CaCO}_{3}$ in very fine particles that release $\mathrm{Ca}^{++}$ into the solution, giving rise to increased $\mathrm{Ca}^{++}$, and eventually $\mathrm{Ca}^{++}+\mathrm{Mg}^{++}$.

\subsection{Micronutrients}

The soil micronutrients that have been analyzed on this survey ( $\mathrm{Fe}, \mathrm{Mn}, \mathrm{Zn}$, and $\mathrm{Cu}$ ) have provided data that indicates that the soils of project area are deficient in the available forms. The amounts being present in content are far below the crop requirements. The high soil $\mathrm{pH}$ and calcareous reaction of soil matrix apparently, are the main constrains to the availability of all determined micronutrients (DTPA test), which are evaluated in Table 7 [18].

Table 7: Evaluation of Soil Micronutrients (ppm) in the Soils of the KIII and KIV Areas

\begin{tabular}{|c|c|c|c|c|}
\hline Grade & Fe & Mn & Zn & Cu \\
\hline Low & $<2.0$ & $<1.8$ & $<1.0$ & $<0.5$ \\
& & $(\mathbf{1 5 . 5 )}$ & $\mathbf{( 0 . 1 7 )}$ & \\
\hline Moderate & $\begin{array}{c}2.0-4.0 \\
(\mathbf{2 . 9 )}\end{array}$ & - & $1.0-1.5$ & - \\
& $>4.0$ & $>1.8$ & $>1.5$ & $>0.5$ \\
\hline Adequate & & & & $\mathbf{( 0 . 9 5 )}$ \\
\hline
\end{tabular}

The figures between brackets like (15.5) indicate averages in the soils of the project area while others indicate the ratings values [19]. Table 6.1 shows that $\mathrm{Mn}$ and $\mathrm{Zn}$ are low, $\mathrm{Fe}$ is moderate, while $\mathrm{Cu}$ is adequate. Zinc and Manganese deficiency is highly probable.

\subsection{Salinity and Sodicity}

Soil salinity and alkalinity (sodicity) can impose an adverse effect on crop performance and yield by limiting plant nutrients uptake and affecting soil moisture characteristics. The soil survey field operations in Kenana III and Kenana IV involved determinations of $\mathrm{pH}, \mathrm{EC}$ and SAR to assess these 
risks. Samples were collected from 0-30, 30-60 and 60-90 cm depths, from 2,616 auger observations in Kenana III and 4,481 in Kenana IV. For carrying out these determinations the method of 1:5 soilwater suspensions was adopted (Table 8 and 9).

\subsubsection{Salinity}

The laboratory results show that the area in general may be classified as non-saline. The content of soluble salts are very low, such that it is considered that the growth of even sensitive crops would not be affected. The EC of the saturation extracts for all samples very rarely exceeds $4 \mathrm{dS} / \mathrm{m}$ at $25^{\circ} \mathrm{C}$. The types of soluble salts were determined for all samples collected. Soluble sulphates are the most dominant followed by chlorides. Bicarbonates are present in small amounts; carbonate is the least found, and completely lacking in many profiles (Table 8 and 9).

\subsubsection{Sodicity}

Calcium and magnesium are the dominant exchangeable cations but at increasing depth, their relative percentage decreases, whereas sodium increases in lower horizons. Some horizons below the surface, and at variable depths, have ESP values more than 15; the limit set up by the USDA's Salinity Laboratory at Riverside in California [18]. For long this was widely accepted for the definition of sodic soils. Local experience [23], at least with the Sudanese Vertisols has indicated that some relaxation was needed, and this limit may be increased to a value within the range of (25-35) before the adverse effect of exchangeable sodium is clearly shown in locally adapted field crops grown in this area. The performance of crops did not show a decline in yield that could be attributed to exchangeable sodium at the above mentioned range. Perhaps, the combination of high clay content and high CEC might have imparted a buffering effect to the harmful level of exchangeable sodium. In general terms, high ESP values have a greater deleterious effect upon soils with 2:1 lattice clays than on those with 1:1 clays [15]. However, although the onset of adverse physical conditions occurs generally at lower ESP levels in montmorillonitic soils, further comparatively large increases in Na content may not cause much additional deterioration.

Table 8: Ranges of pH, EC and SAR Values in $\mathrm{K} \mathrm{III}$

\begin{tabular}{|c|c|c|c|c|c|c|c|c|c|}
\hline \multirow[b]{2}{*}{$\begin{array}{c}\text { Soil } \\
\text { Horizon }\end{array}$} & \multicolumn{3}{|c|}{$\mathrm{pH}$} & \multicolumn{3}{|c|}{ EC } & \multicolumn{3}{|c|}{ SAR } \\
\hline & Range & $\begin{array}{c}\text { No of } \\
\text { observation } \\
\text { s } \\
\text { with } \\
\text { pH values } \\
>8.5\end{array}$ & $\%$ & Range & $\begin{array}{c}\text { No of } \\
\text { observation } \\
s \\
\text { With } \\
\text { EC values } \\
\geq 2.5\end{array}$ & $\%$ & Range & $\begin{array}{c}\text { No of } \\
\text { observatio } \\
\text { ns } \\
\text { With } \\
\text { SAR values } \\
\geq 12\end{array}$ & $\%$ \\
\hline Surface & $\begin{array}{l}7.1- \\
9.2 \\
\end{array}$ & 155 & 6.0 & $0.1-2.5$ & 5 & 0.2 & $\begin{array}{l}1.1- \\
12.5\end{array}$ & 1 & 0.04 \\
\hline Subsoil & $\begin{array}{l}7.2- \\
9.6\end{array}$ & 300 & 11.0 & $0.1-3.8$ & 11 & 0.4 & $\begin{array}{l}2.1- \\
33.2\end{array}$ & 10 & 0.4 \\
\hline
\end{tabular}

Total soil observations in $\mathrm{KIII}=2696$ (2616 augers +80 profiles) [6] 
El-Abbas. Doka M. Ali, John Aitken, Neil R. Munro; Investigating the Properties of the Vertisols at Kenana III and IV Towards Enhancing Management Practices (Sennar State - Sudan). Advances in Image and Video Processing, Volume 5 No 5, October (2017); pp: 11-20

Table 9: Range of pH, EC and SAP Values in Kenana IV

\begin{tabular}{|c|c|c|c|c|c|c|c|c|c|}
\hline \multirow[b]{2}{*}{$\begin{array}{c}\text { Soil } \\
\text { Horizon }\end{array}$} & \multicolumn{3}{|c|}{$\mathrm{pH}$} & \multicolumn{3}{|c|}{ EC } & \multicolumn{3}{|c|}{ SAR } \\
\hline & Range & $\begin{array}{c}\text { No of } \\
\text { observations } \\
\text { with } \\
\text { pH values } \\
>8.5 \\
\end{array}$ & $\%$ & Range & $\begin{array}{c}\text { No of } \\
\text { observations } \\
\text { With } \\
\text { EC values } \\
\geq 2.5 \\
\end{array}$ & $\%$ & Range & $\begin{array}{c}\text { No of } \\
\text { observations } \\
\text { With } \\
\text { SAR values } \\
\geq 12 \\
\end{array}$ & $\%$ \\
\hline Surface & 7.4-9.3 & 50 & 1.1 & $0.1-2.5$ & 2 & 0.04 & $0.3-13$ & 2 & 0.5 \\
\hline Subsoil & 7.3-9.1 & 125 & 2.8 & $1.0-21$ & 6 & 0.13 & $0.9-26$ & 25 & 0.6 \\
\hline
\end{tabular}

Total soil observations in KIV $=1520$ (1475 augers +45 profiles) [6]

Table 8 and Table 9 indicates that moderate soil alkalinity occurs in higher values (> 8.5) in Kenana III area particularly within the soil substratum, compared to values recorded in Kenana IV. This situation could possibly be created as a result of the effect of relatively more moist climatic conditions prevailing in Kenana III area with possible movement of salts into the substratum (subsoil) due to availability of moisture. Similarly, this holds applicable for both the salinity (EC) and sodicity (SAR). The three tested parameters are commonly mild or nearly optimum in Kenana IV more than they are in Kenana III. Therefore, the adverse effect on the availability of nutrient elements would not be to the limit that renders low fertility statues. But the field descriptions of both areas revealed a slightly to moderately calcareous matrix which usually contains very fine particles of $\mathrm{CaCO}_{3}$ which may enhance release of some calcium when the sample is shaken in the laboratory for the high soil: water (1:5) suspension. Furthermore, gypsum crystals will have similar performance releasing more calcium. Therefore, underestimated SAR values are obtained when applying the above mentioned SAR formula.

Useful to review the previous work [4] regarding the earlier (1951-52) reconnaissance soil survey carried out in the Kenana area (the present Kenana III in this project). On this early study 176 soil samples were collected. The salt percentage and sodium value were determined on these samples using soil water extract, and further converted into EC and ESP [19]. The following values are assigned in Table 10.

Table 10: Salt percentage and ESP values

\begin{tabular}{|c|c|c|c|}
\hline \multicolumn{2}{|c|}{ EC $_{\mathbf{e}}$} & \multicolumn{2}{c|}{ ESP } \\
\hline 175 observation & $0-4$ & 116 observation & $0-10$ \\
\hline 1 observation & $>4.0$ & 60 observation & $>10-12$ \\
\hline
\end{tabular}

(Determined by Coyne et Bellier and Hunting Technical Service in 1977 [4])

These values in these categories fairly coincide with the findings obtained from Kenana III and Kenana IV project areas which designate the soil survey areas as non-saline and non-sodic. However, since this situation is so far debatable, there seems to be a need for determining the ESP in the saturation extract of some selected samples to set up criteria and standards for further correlation studies.

\section{Conclusions}

The Vertisols have high potential for crop production; but some constraints emerge affecting crop performance and decreasing yields. Those limitations are in fact aspects of land degradation, 
manifested in, 1) water erosion and; 2) deterioration of physical and chemical properties. In the study area, some parameters are management-factors determining e.g. topsoil structure; flat slope favouring uniform distribution of irrigation water through well designed irrigation and drainage network and; sub-soiling preparing seedbed for determining the tillage units (furrows and basins). Those technical inputs [19] if properly used and practiced are unlikely to leave a fragile soil surface susceptible to water erosion. Some other researchers [14] introduced the techniques of conservation tillage incorporating farm residues and also, described the procedures and benefits of minimum or zero-tillage, as farming practices against incidence of water erosion.

Continuous cropping of Vertisols, through time, leads to compaction and eventually develops a compacted layer at the subsurface, reducing porosity, intensity of cracking and obliterating water movement [3]. Such adverse effects are indicators of degraded soil physical properties. To minimize the concurrence of those hazards, management procedures should adhere to land and crop management systems [11], [13]. Parallel to this approach, the fertility status is likely to decline due to intensive farming of some nutrient-depleting crops, but this nutrient deficiency is commandable through implementing the fertilizer programme [16].

For the study area, sustainable land management scenarios [6] will require farming systems development and Action Plans through:

- Establishing research-based station conducting trials on the attributes of the Land Utilization Types, e.g. cultivars; sowing date; irrigation quantity and frequency; fertilizers; farm management units (basins, furrows) and rotation. Worth trying also, is the adaptive research on farmers' fields guiding them get handing the technologies being introduced in the project [12].

- Applying and disseminating agriculture research recommendations to the farmers through efficient extension work to ensure proper management and improved productivity. Similarly, a possibility exists for extrapolating the outcome of farming experience gained in the neighbouring agricultural schemes e.g. The Kenana Sugar Plantation and El-Shawal extension of the Gezira scheme.

- Maintaining balances between cropping intensity and the magnitude of technology input in order to avoid incidence of land degradation hazard, e.g. soil compaction, water erosion and fertility decline.

- Assign head of groups as facilitators for the farmers involved in small farms where their needs can be exposed and met through joint farming activities, increasing yields, upgrading income and improving their socio-economic welfare.

\section{REFERENCES}

[1] Brady N. C. 1974. The Nature and Properties of Soils. 8th edition. Macmillan publishing Co. Inc. New York.

[2] Buursink J. 1971. Soils of Central Sudan. Grafisch Bedrijf Schotanus \& Jens. Utrecht N.V.

[3] Charles, S. Wortmann and Paul, J. Jasa. 2003. Management to Minimize and Reduce Soil Compaction. G896. NebGuide, University of Nebraska-Lincoln. Extension educational programs. Nebraska-Lincoln 
El-Abbas. Doka M. Ali, J ohn Aitken, Neil R. Munro; Investigating the Properties of the Vertisols at Kenana III and IV Towards Enhancing Management Practices (Sennar State - Sudan). Advances in Image and Video Processing, Volume 5 No 5, October (2017); pp: 11-20

[4] Coyne Et. B., Hunting Technical Services Ltd, Sir Alexander Gibb \& Partners, Sir M. MacDonald \& Partners. 1977. Blue Nile Waters Study, Phase IA Availability and Use of Blue Nile Water. Volume 2, Annex I Soils and Land Classification.. Ministry of Irrigation and Hydro-electricity Energy, Khartoum.

[5] Dawoud H. A. 1971 Characterization of two soils from Kenana area of the central clay plain of Sudan M.Sc.Thesis, submitted to University of Aberdeen, U.K

[6] DIU. 2009. Semi Detailed Soil Survey of Kenana III \& Kenana IV Areas. Volume 1: Main Report (Final Report). Dams Implementation Unit, Khartoum. Sudan

[7] FAO. 1995. Integrated Plant Nutrition Systems. FAO Fertilizers and Plant Nutrition Bulletin - No.12

[8] FAO. 2014. World Reference Base for Soil Resources (WRB) - CD-ROM. Prepared by Berding F. R. (et al). FAO, Rome.

[9] FAO, 2006. Guidelines for Soil Description. 4th edition. Rome.

[10] GRAS \& Robertson, 1995. Accompaning Geological Notes to the 1:1,000,000 scale Geological Atlas of the Republic of Sudan. Bulletin 40, Geological Research Authority of the Sudan (GRAS), Khartoum.

[11] Grossman, RB., WD. Nettleton and BR. Brasher. 1985. Application of pedology to plant response prediction For tropical Vertisols Proceeding of the Fifth international Soil classification workshop. Soil study Administration, Khartoum. Sudan

[12] Ishag H.M. and Said M.B 1985. Groundnut Production irrigated Vertisols of Gezira, Achievements and Problems. In: proceedings of The Fifth international soil Classification workshop. Soil Study Administration, Khartoum. Sudan.

[13] Lal. R. 1995. Tillage Systems in the Tropics. Management Options and Sustainability Implications, FAO. Soil Bulletin-75. Rome, FAO.

[14] Lal R. 1985. A soil suitability guide for different tillage systems in the tropics, Soil and Tillage Research 5: 179-196.

[15] Landon, R. (editor). 1991. Booker Tropical Soil Manual - A handbook for soil study and agricultural land evaluation in the tropics and subtropics Paperback Edition, Longman Scientific Technical Copublished in USA with John Wiley \& Sons. Inc. New York

[16] Murthy, A. S. A. (editor). 1985. Soil fertility management in relation to agricultural Productivity in the Vertisols of India. In: proceeding of the Fifth international Soil classification workshop, Soil Study Administration, Khartoum. Sudan

[17] Purnell, M.F., J. H. Verma and Omar Khodary. 1976. Soil Resource Regions of the Blue Nile, While Nile, Gezira and Khartoum province of the Sudan Soil Study Report No.80. Wad Medani: Soil Study Administration 